\title{
Effects of luteinizing hormone and androgen on the development of rat progenitor Leydig cells in vitro and in vivo
}

\author{
Jing-Jing Guo ${ }^{1, *}$, Xue Ma ${ }^{2,3, *}$, Claire Q F Wang ${ }^{1}$, Yu-Fei Ge ${ }^{2}$, Qing-Quan Lian ${ }^{1}$, Dianne O Hardy ${ }^{2}$, Yu-Fei Zhang ${ }^{4}$, \\ Qiang Dong ${ }^{3}$, Yun-Fei $\mathrm{Xu}^{5}$ and Ren-Shan $\mathrm{Ge}^{1,2}$
}

Progenitor Leydig cells are derived from stem cells. The proliferation and differentiation of progenitor Leydig cells significantly contributes to Leydig cell number during puberty. However, the regulation of these processes remains unclear. The objective of the present study was to determine whether luteinizing hormone (LH) or androgen contributes to the proliferation and differentiation of progenitor Leydig cells. Fourteen-day-old male Sprague-Dawley rats were treated for $\mathbf{7}$ days with NalGlu, which is a gonadotropinreleasing hormone antagonist, to reduce the secretion of $\mathrm{LH}$ in the pituitary and thus, androgen in the testis. Rats were co-administered with LH or 7 $\alpha$-methyl-nortestosterone (MENT), which is an androgen resistant to metabolism by $5 \alpha$-reductase 1 in progenitor Leydig cells, and the subsequent effects of $\mathrm{LH}$ or androgen were measured. ${ }^{3} \mathrm{H}$-Thymidine was also intravenously injected into rats to study thymidine incorporation in progenitor Leydig cells. Progenitor Leydig cells were examined. NalGlu administration reduced progenitor Leydig cell proliferation by $83 \%$. In addition, LH or MENT treatment restored Leydig cell proliferative capacity to $73 \%$ or $50 \%$ of control, respectively. The messenger RNA levels of proliferation-related genes were measured using real-time PCR. The expression levels of Igf1, Lifr, Pdgfra, Bc/2, Ccnd3 and Pcnawere upregulated by MENT, and those of $P d g f r a, C c n d 3$ and $P c n a$ were upregulated by LH. Both LH and MENT stimulated the differentiation of progenitor Leydig cells in vitro. We concluded that both LH and MENT were involved in regulating the development of progenitor Leydig cells.

Asian Journal of Andrology (2013) 15, 685-691; doi:10.1038/aja.2013.55; published online 24 June 2013

Keywords: luteinizing hormone; progenitor Leydig cell; proliferation; testosterone

\section{INTRODUCTION}

Testosterone, which is secreted by Leydig cells in the testis, is the main androgen in circulation. The postnatal development of adult Leydig cells in the rat can be conceptually divided into three distinct stages: progenitor, immature and adult Leydig cells. The first committed Leydig cell is the progenitor Leydig cell. It is spindle-shaped and expresses the Leydig cell lineage biomarker $3 \beta$-hydroxysteroid dehydrogenase 1 (3ßHSD1) and appears in the interstitium around postnatal days $11-14 .^{1,2}$ During the first week after the appearance of progenitor Leydig cells, these cells rapidly divide to increase Leydig cell numbers ${ }^{3}$ and then differentiate into immature Leydig cells at day 28 postpartum. ${ }^{4}$

However, the hormonal control of Leydig cell proliferation and differentiation is less well understood in the progenitor Leydig cell compared to the immature or adult Leydig cell, but several factors are known to be involved. These factors include luteinizing hormone (LH), insulin-like growth factor-1 (IGF-1), transforming growth factor $\alpha$, transforming growth factor $\beta$, interleukin 1 , thyroid hormone, anti-mullerian hormone and androgen. ${ }^{4,5}$ Progenitor Leydig cells are less sensitive to $\mathrm{LH}$ stimulation for its steroidogenesis compared to that of androgen, ${ }^{6}$ perhaps due to the higher number of androgen receptors compared to the LH receptors (LHCGR) expressed by the rat progenitor Leydig cell. ${ }^{6}$ Androgen may also affect the development of progenitor Leydig cells because testicularly feminized mouse testes exhibit a lower Leydig cell number, and androgen may effect steroidogenesis due to androgen insensitivity. ${ }^{7,8}$ However, the method by which $\mathrm{LH}$ and androgen regulate the development of progenitor Leydig cells still remains unclear. The objective of the present study was to investigate the effects of $\mathrm{LH}$ and androgen on the development of progenitor Leydig cells in vivo and in vitro.

\section{MATERIALS AND METHODS}

\section{Materials}

NalGlu (NAL [Ac-D2Nal1,D4-ClPhe2,D3Pal3,Arg5,DGlu6(AA),DAla10], a synthetic gonadotropin-releasing hormone antagonist that is used to suppress endogenous $\mathrm{LH},{ }^{9}$ was provided by Dr Jean Rivier (Salk Institute, San Diego, CA, USA). Hyamine hydroxide was purchased from ICN Radiochemicals (Irvine, CA, USA). ${ }^{3} \mathrm{H}$-Thymidine was purchased from

${ }^{1}$ The 2nd Affiliated Hospital, Wenzhou Medical College, Wenzhou 325027, China; ${ }^{2}$ Population Council \& Rockefeller University, New York, NY 10065, USA; ${ }^{3}$ Department of Urology, West China Hospital, Sichuan University, Chengdu 610041, China; ${ }^{4}$ Mudanjiang Medical College, Mudanjiang 157011 , China and ${ }^{5}$ Department of Urology, the Affiliated 10th People's Hospital of Tongji University, Shanghai 200072, China

* These authors equally contributed to this work.

Correspondence: Professor RS Ge (r_ge@yahoo.com) and Professor YF Xu (xuyunfeibb@sina.com)

Received: 2 January 2013; Revised: 16 February 2013; Accepted: 8 April 2013; Published online: 24 June 2013 
DuPont-New England Nuclear (Boston, MA, USA). LH was a gift from NIDDK. Because progenitor Leydig cells in the 14-day-old rat testis exhibited high levels of $5 \alpha$-reductase 1 and $3 \alpha$-hydroxysteroid dehydrogenase activities, ${ }^{10}$ which readily metabolized testosterone into weak androgen androsterone, a synthetic $5 \alpha$-reductase-resistant androgen $7 \alpha$-methyl-19nortestosterone (MENT), which is resistant to $5 \alpha$-reductase $1,{ }^{10,11}$ was used. MENT was 10 times more potent than testosterone in binding to the androgen receptor. ${ }^{10,11}$ MENT was kindly provided by the Upjohn Company (Kalamazoo, MI, USA). Sprague-Dawley rats (dams with litters of male pups) were purchased from Charles River Laboratories (Wilmington, MA, USA). The animal protocols were approved by the Institutional Animal Care and Use Committee of the Rockefeller University and conducted in accordance with the National Institutes of Health Guide for the Care and Use of Laboratory Animals.

\section{Methods}

Animals and treatment. Male pups from postnatal day 14, a time in which progenitor Leydig cells are formed, ${ }^{4}$ were randomly divided into four groups with 40 animals per group. Three sets of experiments were performed. To suppress the endogenous secretion of LH and androgen, NAL was administered daily via intraperitoneal injection. The rats were treated with hormones for 7 days as follows: (i) control (CON) rats received an injection of $8 \%$ mannitol (vehicle); (ii) rats in the second group (NAL group) received intraperitoneal injections of NAL (which was dissolved in $8 \%$ mannitol) at a dose of $10 \mu \mathrm{g} \mathrm{day}^{-1}$; (iii) rats in the third group (NAL $+\mathrm{LH}$ group) received injections of NAL plus $5 \mu \mathrm{g}$ LH per day; and (iv) rats in the fourth group (NAL+MENT group) received injections of NAL plus $25 \mu \mathrm{g} \mathrm{day}^{-1}$ MENT. Doses of LH or MENT were adopted according to previously reported observations. ${ }^{11}$ Each hormone was dissolved in $8 \%$ mannitol and injected in the rats $(0.1 \mathrm{ml}$ per rat $)$ twice per day. The treatment began on day 14 postpartum, and the animals were sacrificed on day 21 by asphyxiation with $\mathrm{CO}_{2}$.

In vivo ${ }^{3} \mathrm{H}$-thymidine incorporation. After 7 days of hormonal treatment, half of the rats in each group received $1 \mu \mathrm{Ci} \mathrm{g}^{-1}$ body weight ${ }^{3} \mathrm{H}$ thymidine by intraperitoneal injection. The rats were euthanized by $\mathrm{CO}_{2}$ exactly $2 \mathrm{~h}$ later. The testes were removed and grouped according to the treatment for the isolation of progenitor Leydig cells.

Cell isolation. Both ${ }^{3} \mathrm{H}$-thymidine-treated and untreated rats were used for the isolation of progenitor Leydig cells. The isolation procedure for the progenitor Leydig cells was performed as previously described. ${ }^{12}$ Briefly, testes from five 21-day-old rats after hormonal treatment were removed. Decapsulated testes were dispersed with $0.25 \mathrm{mg} \mathrm{ml}^{-1}$ collagenase (collagenase-D; Boehringer Mannheim Biochemicals, Indianapolis, IN, USA) in medium 199 for $10 \mathrm{~min}$ at $34{ }^{\circ} \mathrm{C}$ with shaking. The separated cells were filtered through two layers of nylon mesh, centrifuged at $250 \mathrm{~g}$ and resuspended in $55 \%$ isotonic Percoll. Followed by density gradient centrifugation at $25000 \mathrm{~g}$ for $45 \mathrm{~min}$ at $4{ }^{\circ} \mathrm{C}$, the progenitor Leydig cell fraction was collected between densities of 1.064 and $1.070 \mathrm{~g} \mathrm{ml}^{-1}$. The cells were washed with Hank's buffered salt solution, centrifuged at $250 \mathrm{~g}$ and then resuspended in phenol red-free Dulbecco's modified Eagle medium: Nutrient mixture F-12 (DMEM-Ham's F-12) medium (D-2906; Sigma Chemical Co., St Louis, MO, USA) supplemented with $1 \mathrm{mg} \mathrm{ml}^{-1}$ bovine serum albumin. Three replicates of the isolation were performed. The purity of the progenitor Leydig cells was determined by performing immunohistochemical staining of $3 \beta \mathrm{HSD} 1$, using $0.4 \mathrm{mmol}^{-1}$ etiocholanolone as substrate and $\mathrm{NAD}+$ as cofactor according to a previously described method. ${ }^{13}$ Enrichment of the progenitor Leydig cells was typically up to $95 \%$ purity.

Ex vivo ${ }^{3} H$-thymidine incorporation. Progenitor Leydig cells $\left(0.2 \times 10^{6}\right.$ cells) isolated from rats after hormonal treatment for 7 days (at postnatal day 21) without ${ }^{3} \mathrm{H}$-thymidine treatment were incubated in DMEM-Ham's F-12 medium containing $1 \mu \mathrm{Ci} \mathrm{ml}{ }^{-1}{ }^{3} \mathrm{H}$-thymidine for $2 \mathrm{~h}$. The media was decanted from the cells after centrifugation.

Measurement of radioactivity. Triplicate aliquots of $1 \times 10^{6}$ cells from ${ }^{3} \mathrm{H}$-thymidine-treated rats in each group were dispensed into $1.5 \mathrm{ml}$ microcentrifuge tubes. Both cells from the in vivo and in vitro treatment of ${ }^{3} \mathrm{H}$-thymidine were pelleted after centrifugation at $250 \mathrm{~g}$ for $10 \mathrm{~min}$ and the cells were washed twice using phosphate buffered saline. The cells were dissolved with $0.15 \mathrm{ml}$ hyamine hydroxide, and radioactivity was measured in a liquid scintillation counter as previously described. ${ }^{5}$

Histological analysis. Five testes were randomly collected from each of the four groups and perfused after punching three holes in each testis using a needle. Subsequently, the testes were fixed by immersion with $2.5 \%$ glutaraldehyde, $1 \%$ acrolein in $0.1 \mathrm{~mol}^{-1}$ sym-collidine buffer, $1 \%$ osmium for postfixation and $1.5 \%$ potassium ferricyanide, and were then embedded in Epon-araldite resin. Testicular sections were cut at a thickness of $3 \mu \mathrm{m}$ and stained with $1 \%$ toluidine blue to identify mesenchymal cells and progenitor Leydig cells, as previously described. ${ }^{3}$ Mesenchymal cells are characterized as fusiform cells and do not touch the basal lamina of the seminiferous tubule or the vascular endothelium. Progenitor Leydig cells were identified by their abundant, darkly stained cytoplasm and irregular nuclei. The morphology of progenitor Leydig cells was oval-like or round. Other interstitial cell types including macrophages, pericytes and endothelial cells were identified according to a previously published method. ${ }^{3}$ The number of progenitor Leydig cells, mesenchymal cells and other interstitial cells were quantified, according to the fractionator technique. ${ }^{3,11}$ Approximately 10 sections were sampled from each testis. The total number of interstitial cells was calculated by multiplying the number of interstitial cells quantified in a known fraction of the testis by the inverse of the sampling probability. The percentage of each cell type of the total number of interstitial cells was calculated for statistical analysis. $^{3,11}$

Cell culture and in vitro hormonal treatment. Progenitor Leydig cells obtained from normal 14-day-old rat testes were also purified according to the previously described method. Progenitor Leydig cells were cultured for $48 \mathrm{~h}$ in phenol red-free medium (DMEM-Ham's F12) supplemented with $1 \mathrm{mg} \mathrm{ml}^{-1}$ bovine serum albumin, $1 \mathrm{mg} \mathrm{ml} \mathrm{mg}^{-1}$ bovine lipoprotein and $25 \mathrm{~m} \mathrm{~mol} 1^{-1}$ HEPES ( $\mathrm{pH} \mathrm{7.2)} \mathrm{in} \mathrm{a} 34{ }^{\circ} \mathrm{C}$, $5 \% \mathrm{O}_{2}$ in a $5 \% \mathrm{CO}_{2}$ humidified incubator. In the animal groups that received in vitro hormonal treatment, Leydig cells were first cultured for $24 \mathrm{~h}$ in hormone-free medium. The media were then removed and replaced with fresh medium containing either $1 \mathrm{ng} \mathrm{ml}^{-1}$ ovine $\mathrm{LH}$; $50 \mathrm{n} \mathrm{mol}^{-1}$ MENT or $1 \mathrm{ng} \mathrm{ml}^{-1}$ LH plus $50 \mathrm{n} \mathrm{mol}^{-1}$ MENT in vitro for 7 days. The concentrations of LH and MENT used in the present experiment were selected based on their effective action on the proliferation of progenitor Leydig cells, as described in our previous study. ${ }^{5}$ The medium was changed daily and collected for the measurement of androsterone, which is a primary androgen produced by progenitor Leydig cells, ${ }^{10}$ and testosterone. 
Radioimmunoassay for androsterone and testosterone. The radioimmunoassay for androsterone and testosterone was performed as previously described, ${ }^{10}$ using a specific antibody against either androsterone or testosterone. Androsterone was measured because progenitor Leydig cells secrete this steroid at approximately $80 \%$ of total androgen levels. ${ }^{10}$ The intrassay and interassay coefficients of variation were within $15 \%$ for radioimmunoassay.

Quantitative real-time PCR analysis. Total RNAs were extracted from the isolated progenitor Leydig cells $\left(1 \times 10^{6}\right.$ cells) in Trizol (Invitrogen, Carlsbad, CA, USA), according to the manufacturer's instructions. The RNAs were reverse transcribed into cDNAs in the presence of random primers and the M-MLV reverse transcriptase (Promega Biosciences, Inc., San Luis Obispo, CA, USA). Quantitative PCR in the presence of SYBR green was performed on an ABI 7700 system (PE Applied Biosystems, Carlsbad, CA, USA). Messenger RNA measurements were normalized against an internal control, which was the ribosomal protein S16 (Rps16). All control Cycle threshold $\left(C_{\mathrm{t}}\right)$ values were corrected by the median difference between the samples and Rps16. The $C_{\mathrm{t}}$ values for Igf1, Lifr, Pdgfra, Bcl2, Ccnd3, Pcna, Nr5a1, Hsd3b1, Kit and Rps16 were 22, 17, 16, 20, 19, 20, 17, 19, 21 and 16, respectively. The primer sequences used and full gene names are listed in Table 1.

Statistical analysis. Data were expressed as the mean \pm s.e.m. A oneway ANOVA with Tukey's post hoc analysis was used to determine differences between two groups when more than three groups were compared using GraphPad (Version 5; GraphPad Software, Inc., San Diego, CA, USA). Differences were regarded as statistically significant at $P<0.05$. All of the measurements were repeated at least three times.

\section{RESULTS}

Testis weights, morphology and percentage of interstitial cells after hormonal treatment

As shown in Figure 1, NAL treatment significantly decreased the testis weight when compared to control $(P<0.001)$. Administration of $\mathrm{LH}$ or MENT in NAL-treated rats partially restored the loss of testis weights. The progenitor Leydig cells were oval-shaped with abundant

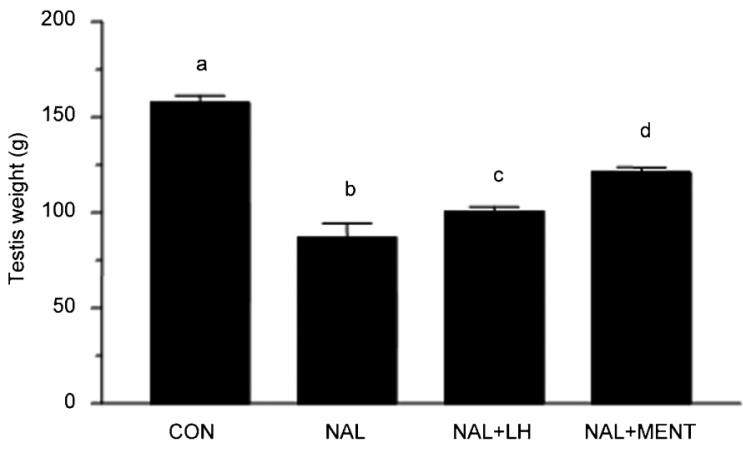

Figure 1 Effects of hormonal treatment on the testis weights of rats. Male pups were treated without (CON) or with NalGlu (NAL), NalGlu plus LH (NAL+LH) and NalGlu plus MENT (NAL+MENT) from postnatal days 14 to 21 (mean \pm s.e.m., $n=10$ ). The identical letter indicates that there was no significant difference between two groups at $P<0.05$. LH, luteinizing hormone; MENT, $7 \alpha$-methylnortestosterone.

cytoplasm in the testis of the control rat (Figure 2). Mesenchymal cells (Figure 2a) were spindle-shaped cells located in the central regions of the interstitial space with little cytoplasm and did not touch the basal lamina of the seminiferous tubule or the vascular endothelium. Other cells included endothelial cells, macrophages and pericytes.

The average number of cells per testis 7 days after hormonal treatment is shown on Table 2. After the administration of NAL, few progenitor Leydig cells were observed, and the mesenchymal cells became the major cell type in the interstitial area (Figure $2 \mathbf{b}$ ). Moreover, treatment with NAL plus LH or NAL plus MENT partially restored the number of progenitor Leydig cells in the interstitial area (Figures $2 \mathrm{c}$ and $\mathbf{d}$ and $\mathbf{3}$ ). The percentage of progenitor Leydig cells, mesenchymal cells and other interstitial cells and their absolute numbers were further quantitatively calculated. NAL treatment has been shown to increase the percentage and absolute number of mesenchymal cells and decrease the number of progenitor Leydig cells, while administration with LH or MENT in NAL-treated rats partially restored the percentage and absolute number of progenitor Leydig cells of total interstitial cells (Figure 3). The total number of interstitial cells was not affected in all groups.

Table 1 Primer sequences and PCR product sizes

\begin{tabular}{|c|c|c|c|}
\hline Gene name & Gene symbol & Primer sequence & $P C R$ size $(b p)$ \\
\hline \multirow[t]{2}{*}{ Insulin-like growth factor 1} & $\operatorname{lgf1}$ & Forward: 5'-ACTCTGCTTGCTCACCTTTACC-3' & 174 \\
\hline & & Reverse: 5'-TCATCCACAATGCCCGTC-3' & \\
\hline \multirow[t]{2}{*}{ Leukemia inhibitory factor receptor } & Lifr & Forward: 5'-GCTGACTTCTCGACCTCCA-3' & 310 \\
\hline & & Reverse: 5'-GGTATTACGCGTCCAGGA-3' & \\
\hline \multirow[t]{2}{*}{ Platelet-derived growth factor receptor $\alpha$ peptide } & Pdgfra & Forward: 5'-ACCTTGCACAATAACGGGAG-3' & 336 \\
\hline & & Reverse: 5'-CAGTTTGATGGACGGGAGTT-3' & \\
\hline \multirow[t]{2}{*}{ B-cell lymphoma 2} & $B c / 2$ & Forward: 5'-AGCGTCAACAGGGAGATGTC-3' & 204 \\
\hline & & Reverse: 5'-TATGCACCCAGAGTGATGCA-3' & \\
\hline \multirow[t]{2}{*}{ G1/S-specific cyclin-D3 } & Ccnd3 & Forward: 5'-AGGCACTGGTCAAAAAGCAT-3' & 191 \\
\hline & & Reverse: 5'-GTCCACTTCAGTGCCTGTGA-3' & \\
\hline \multirow[t]{2}{*}{ Proliferating cell nuclear antigen } & Pcna & Forward: 5'-GCCCTCAAAGACCTCATCAA-3' & 338 \\
\hline & & Reverse: 5'-TCTGGGATTCCAAGTTGCTC-3' & \\
\hline \multirow[t]{2}{*}{ Steroidogenic factor 1} & Nr5al & Forward: 5'-CAGAGCTGCAAAATCGACAA-3' & 186 \\
\hline & & Reverse: 5'-CCCGAATCTGTGCTTTCTTC-3' & \\
\hline \multirow[t]{2}{*}{ 3ß-hydroxysteroid dehydrogenase I } & $H s d 3 b 1$ & Forward: 5'-CCCTGCTCTACTGGCTTGC-3' & 178 \\
\hline & & Reverse: 5'-TCTGCTTGGCTTCCTCCC-3' & \\
\hline \multirow[t]{2}{*}{ Kit } & Kit & Forward: 5'-GGGGATCATTGTGATGGT-3' & 308 \\
\hline & & Reverse: 5'-GACATTAGGGCCTCCCTTT-3' & \\
\hline \multirow[t]{2}{*}{ Ribosomal protein S16 } & Rps16 & Forward: 5'-AAGTCTTCGGACGCAAGAAA-3' & 148 \\
\hline & & Reverse: 5'-TTGCCCAGAAGCAGAACAG-3' & \\
\hline
\end{tabular}




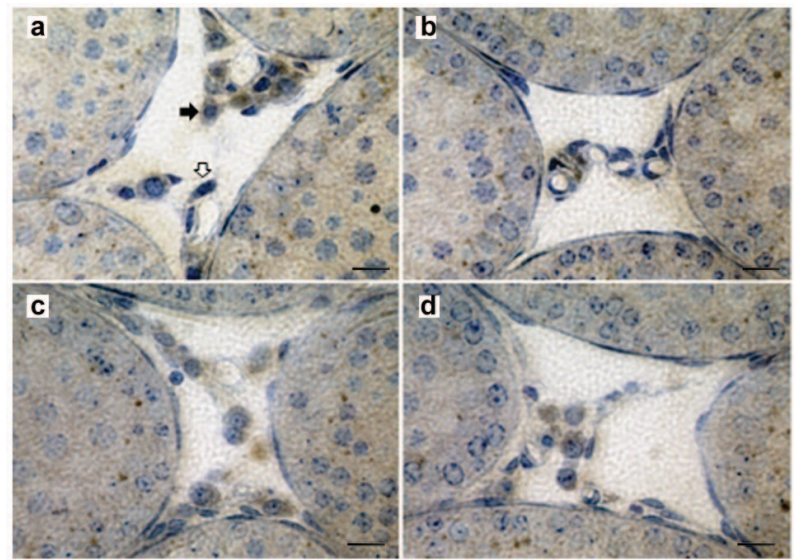

Figure 2 Effects of hormonal treatment on rat interstitial morphology. There were numerous progenitor Leydig cells (indicated by the black arrow) and putative mesenchymal-like mesenchymal cells (indicated by the white arrow) in the control group (a). Few progenitor Leydig cells were detected (b) in the testicular interstitial areas after NalGlu (NAL) treatment. The partially restored interstitial histology presented in the NAL+LH (c) and NAL+MENT (d) groups (scale bar $=10 \mu \mathrm{m}$ ). LH, luteinizing hormone; MENT, 7 $\alpha$-methyl-nortestosterone.

In vivo and ex vivo thymidine incorporation of isolated progenitor Leydig cells

Thymidine incorporation by progenitor Leydig cells was measured to examine the proliferative capacity of progenitor Leydig cells in vivo and in vitro. As shown in Figure 4, thymidine incorporation in progenitor Leydig cells was significantly reduced to only $17 \%$ of control levels after NAL treatment as shown in both in vivo (Figure 4a) and ex vitro (Figure $\mathbf{4 b}$ ) thymidine incorporation studies. Compared to NAL treatment, LH or MENT administration in NAL-treated rats resulted in higher thymidine incorporation levels, which were $73 \%$ and $50 \%$ of control levels, respectively. These data indicated that LH and MENT were required for the maintenance of the proliferative capacity of progenitor Leydig cells.

Messenger RNA levels of proliferation-related genes in progenitor Leydig cells

We isolated progenitor Leydig cells from each treatment group and measured the mRNA levels of several genes that were expected to have roles in proliferation or differentiation. As shown in Figure 5, NAL treatment significantly reduced mRNA levels of proliferating cell nuclear antigen (Pcna), B-cell lymphoma 2 (Bcl2) and cyclin D3 (Ccnd3), which are genes that encode proteins that are involved in proliferation. NAL also significantly downregulated the expression levels of the growth factor-related genes Igfl, leukemia inhibitory factor receptor (Lifr) and platelet-derived growth factor receptor $\alpha$ polypeptide (Pdgfra).

Table 2 Absolute cell number per testis (millions) after hormonal treatment

\begin{tabular}{lcccc}
\hline Treatment & Leydig cell & Mesenchymal cell & Other cells & Total cell \\
\hline Control & $2.708 \pm 0.202^{\mathrm{a}}$ & $1.151 \pm 0.103^{\mathrm{a}}$ & $1.105 \pm 0.086^{\mathrm{a}}$ & $4.964 \pm 0.243^{\mathrm{a}}$ \\
$\mathrm{NAL}$ & $0.226 \pm 0.071^{\mathrm{b}}$ & $2.762 \pm 0.163^{\mathrm{b}}$ & $1.381 \pm 0.103^{\mathrm{a}}$ & $4.369 \pm 0.219^{\mathrm{a}}$ \\
$\mathrm{NAL}+\mathrm{LH}$ & $1.941 \pm 0.090^{\mathrm{c}}$ & $1.473 \pm 0.117^{\mathrm{a}}$ & $1.381 \pm 0.073^{\mathrm{a}}$ & $4.795 \pm 0.217^{\mathrm{a}}$ \\
$\mathrm{NAL}+\mathrm{MENT}$ & $1.715 \pm 0.291^{\mathrm{c}}$ & $1.243 \pm 0.092^{\mathrm{a}}$ & $1.197 \pm 0.086^{\mathrm{a}}$ & $4.155 \pm 0.375^{\mathrm{a}}$ \\
\hline
\end{tabular}

Abbreviations: LH, luteinizing hormone; MENT, $7 \alpha$-methyl-nortestosterone.

Values are expressed as the mean \pm s.e.m. Within each column, numbers that were not significantly different $(P>0.05)$ share the same letter.
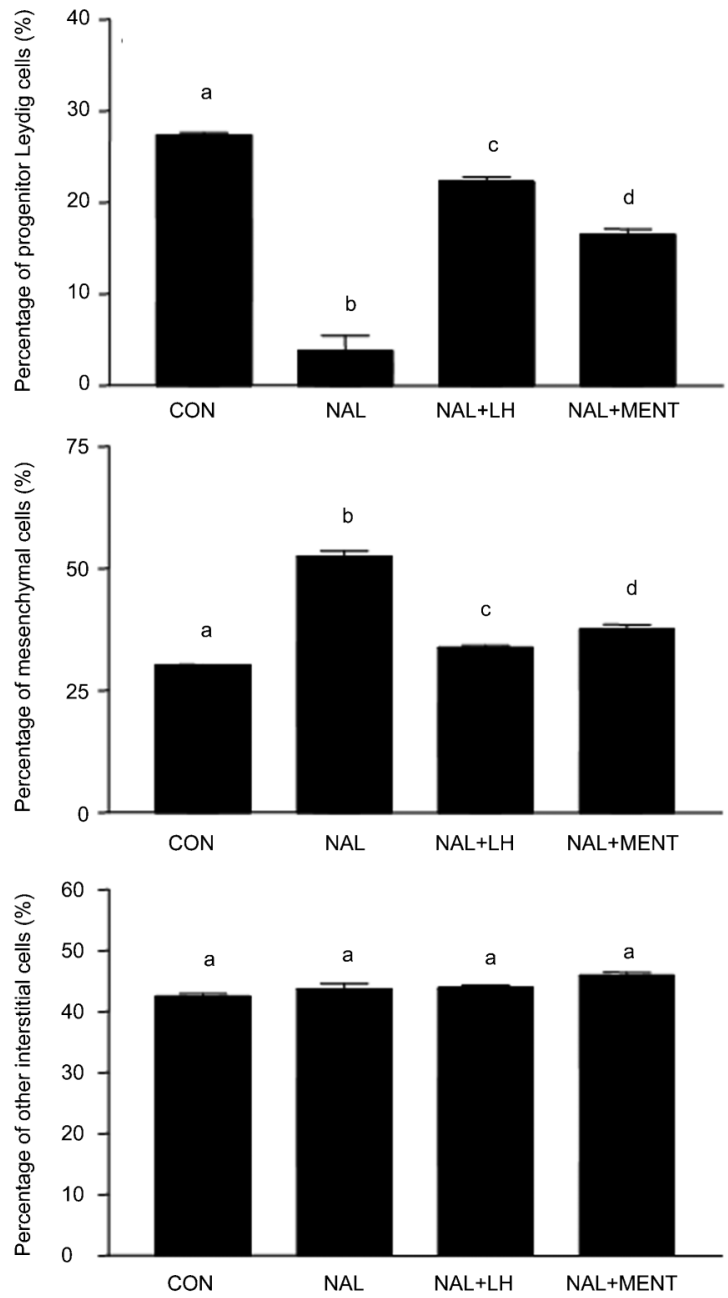

Figure 3 The percentage of PLCs, mesenchymal-like MCs and other interstitial cells of total interstitial cells. Male pups were treated without (CON) or with NalGlu (NAL), NalGlu plus $\mathrm{LH}(\mathrm{NAL}+\mathrm{LH})$ and NalGlu plus MENT (NAL+MENT) from postnatal days 14 to 21 (mean \pm s.e.m., $n=5$ ). An identical letter indicates that there was no significant difference between two groups at $P<0.05$. LH, luteinizing hormone; MC, mesenchymal cell; MENT, 7 $\alpha$-methyl-nortestosterone; PLC, progenitor Leydig cell.

However, there was no change in Kit mRNA levels after hormonal treatment. The expression of Nr5a1 (encoding steroidogenic factor 1) and $H s d 3 b 1$ (encoding 3ßHSD1), which were expected in differentiating cells, was also downregulated. LH or MENT administration in NALtreated rats restored the expression of the proliferative biomarkers Pcna and Ccnd3. However, LH and MENT regulated growth factor-related gene expression differently. LH increased the expression of Pdgfra, but did not affect the level of Igf1, Bcl2 and Lifr, while MENT increased the expressions of Igfl, Pdgfra, Lifr and Bcl2. As expected, LH significantly increased the expression levels of differentiation-related genes, including $\mathrm{Nr} 5 a 1$ and $H s d 3 b 1$. MENT also slightly but significantly increased Nr5a1 expression but did not affect $H s d 3 b 1$. These data suggested that LH and MENT regulated different sets of genes to stimulate progenitor Leydig cell proliferation and/or differentiation.

\section{LH and MENT stimulate the differentiation of progenitor Leydig} cells

We isolated progenitor Leydig cells and cultured them with $\mathrm{LH}$ and MENT alone or in combination for 7 days. As shown in Figure 6, LH 

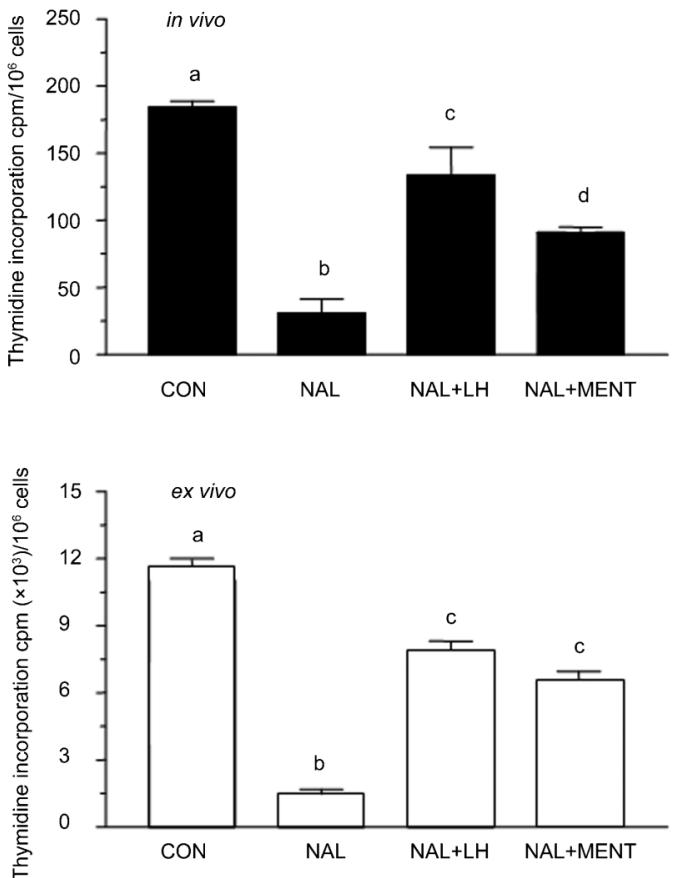

Figure 4 Thymidine incorporation in isolated progenitor Leydig cells after hormonal treatment. Male pups were treated without (CON) or with NalGlu (NAL), NalGlu plus LH (NAL+LH) and NalGlu plus MENT (NAL+MENT) from postnatal days 14 to 21 (mean \pm s.e.m., $n=3$ ). An identical letter indicates that there was no significant difference between two groups at $P<0.05$. LH, luteinizing hormone; MENT, $7 \alpha$-methyl-nortestosterone.

and MENT significantly increased testosterone production, and their combination was synergistic.

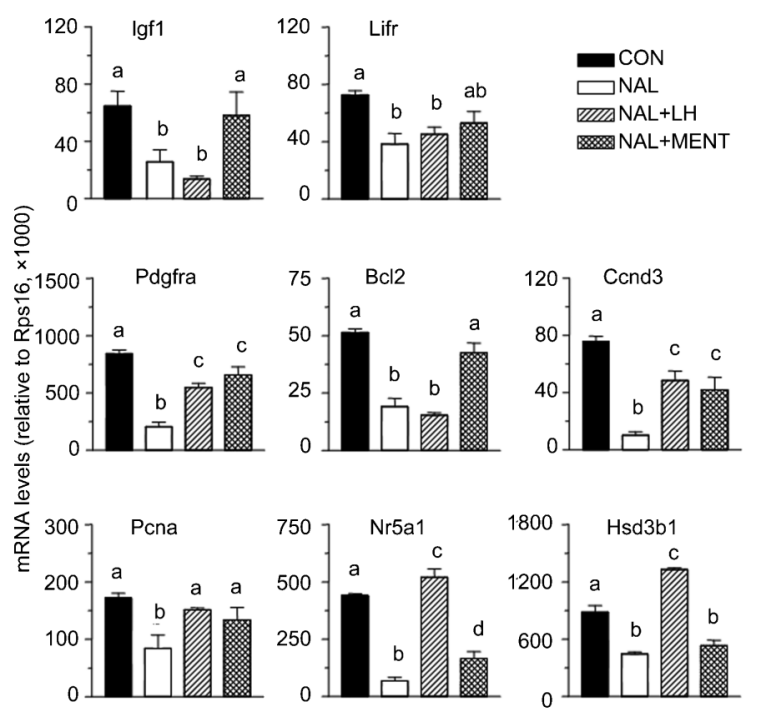

Figure 5 Messenger RNA levels of the target genes. Male pups were treated without $(\mathrm{CON})$ or with NalGlu (NAL), NalGlu plus LH (NAL+LH) and NalGlu plus MENT (NAL+MENT) from postnatal days 14 to 21. The Igf1, Lifr, Pdgfra, Bcl2, Ccnd3, Pcna, Nr5al and Hsd3b1 expression levels were measured in isolated progenitor Leydig cells. The data are shown as the mean \pm s.e.m., $n=3$ preparations. An identical letter indicates that there was no significant difference between two groups at $P<0.05$. LH, luteinizing hormone; MENT, $7 \alpha$-methyl-nortestosterone.

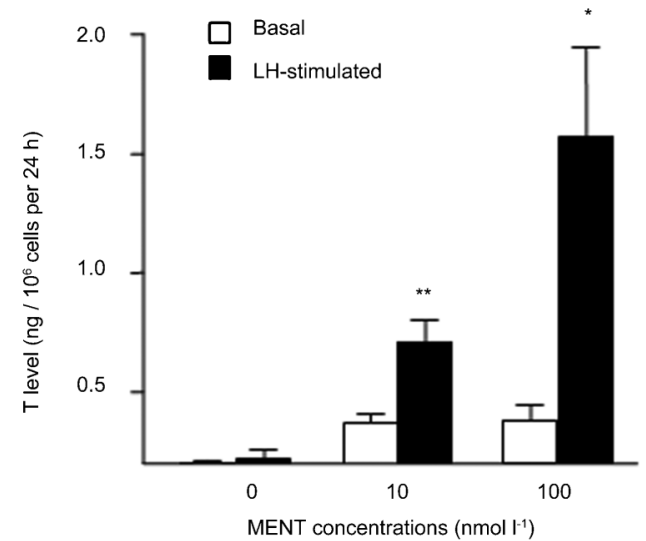

Figure 6 The effects of LH and MENT alone or in combination on testosterone production of progenitor Leydig cells. The data are shown as the mean \pm s.e.m., $n=4$ preparations. $* P<0.05$ or $* * P<0.01$, compared to control (no MENT treatment). LH, luteinizing hormone; MENT, $7 \alpha$-methyl-nortestosterone.

\section{DISCUSSION}

This in vivo study showed that LH and androgen stimulated the proliferation of progenitor Leydig cells in NAL-castrated testes and also regulated different sets of growth factor-related genes. We also demonstrated that in vitro LH and MENT alone could stimulate the differentiation of progenitor Leydig cells.

Previous studies have shown that factors other than LH have roles in the proliferation and differentiation of cells in the Leydig cell lineage. It has been shown that proliferation of precursor cells in the Leydig cell lineage occurs in the absence of LH. ${ }^{14}$ One of these factors is prolactin. Prolactin receptors are expressed on progenitor Leydig cells in the prepubertal rat testis and it was found that prolactin stimulated their proliferation. ${ }^{15}$ Androgen could be another factor. The hypothesis that androgens facilitate the proliferation of Leydig cell precursors is based on the evidence that androgen receptors outnumber $\mathrm{LH}$ receptors in progenitor Leydig cells.

Gonadotropin-releasing hormone antagonists have been used to suppress endogenous LH and androgen. ${ }^{16}$ Treatment with the gonadotropin-releasing hormone antagonist NAL has been demonstrated to reduce testis weight and pituitary LH secretion and thus, lower androgen levels. ${ }^{16}$ Gonadotropin-releasing hormone completely suppresses circulating LH levels, which in turn decreases the cytoplasmic mass of adult Leydig cells. This is associated with an almost undetectable testosterone level (only $6 \%$ of control). ${ }^{17}$ However, some concerns have arisen regarding the mechanism of gonadotropinreleasing hormone antagonist because rat Leydig cells express high affinity gonadotropin-releasing hormone receptors. ${ }^{18}$ However, the blockade of these gonadotropin-releasing hormone receptors with a gonadotropin-releasing hormone antagonist had no direct effect on rat Leydig cell function in vivo, ${ }^{19}$ which may indicate that gonadotropinreleasing hormone antagonists suppress circulatory levels of LH and androgen. In a previous study, NAL, a gonadotropin-releasing hormone antagonist, was used to distinguish the effects of exogenous $\mathrm{LH}$ and androgen on the initial differentiation of Leydig cells from progenitor Leydig cells. ${ }^{11}$ Treatment with NAL induced significant reductions in testis weight (also shown in Figure $\mathbf{1}$ of this study), testosterone production and the cytoplasmic mass of progenitor Leydig cells, and these parameters were partially recovered after coadministration with LH or testosterone. ${ }^{11}$ The partial restoration of testis weight and cytoplasmic mass of progenitor Leydig cells by MENT (a synthetic androgen) was observed in the present study (Figures 1 
and 2). In this study, we also demonstrated that NAL treatment significantly reduced the proliferative capacity of progenitor Leydig cells (Figure 4).

LH is essential for Leydig cell function because it is the principle stimulating hormone of androgen production by adult Leydig cells. ${ }^{4}$ Our present study showed that LH maintained the proliferative capacity of progenitor Leydig cells at $73 \%$ of control levels in the NALtreated testis (Figure 4).

When immature rats were treated with gonadotropin-releasing hormone antagonist and testosterone simultaneously, the morphology of Leydig cell precursors and levels of Leydig cell-specific mRNA levels for Cyp17al and Lhcgr were similar to controls. ${ }^{20}$ In addition, androgen was likely to be required for the differentiation of progenitor Leydig cells. ${ }^{12}$ In the present study, we demonstrated that in vitro culture of MENT significantly increased total androgen production. Although androgen may exert autocrine regulation of progenitor Leydig cell differentiation (Figure 6), we previously demonstrated that androgen did not stimulate progenitor Leydig cell proliferation but stimulated immature Leydig cell proliferation in vitro. ${ }^{5} \mathrm{Xu}$ et al. ${ }^{21}$ also showed that androgen receptors expressed on Leydig cells were not required for Leydig cell proliferation because the number of Leydig cells was normal in Leydig cellspecific androgen acceptor knockout (L-AR-/y) mice. Furthermore, our present study also showed that MENT partially maintained progenitor Leydig cell proliferation in vivo (Figure 3), indicating that this action may exert indirectly via other testicular cell types. In addition to Leydig cells in the testis, Sertoli cells and myoid cells also express androgen receptors. ${ }^{22}$ The in vivo effects of androgens on Leydig cell number are potentially mediated via androgen receptors in Sertoli cells because a significant reduction in mouse Leydig cell number was observed in Sertoli cell-specific knockout androgen receptor mice. ${ }^{23}$ One downstream target of androgen receptors in Sertoli Cells is PDGF-A because PDGF-A mRNA (Pdgfa) levels in these knockout mice were significantly reduced. ${ }^{23}$ Moreover, the myoid cell-specific knockout of androgen receptors did not appear to affect Leydig cell function. ${ }^{24}$

We found that $\mathrm{LH}$ and androgen regulated different sets of genes that were associated with progenitor Leydig cell proliferation and differentiation. LH significantly contributed to the mRNA levels of platelet-derived growth factor receptor $\alpha$ peptide ( $P d g f r a)$ and cyclin D3 (Ccnd3). Platelet-derived growth factor $\alpha$ is required for stimulation of the proliferation of stem and progenitor Leydig cells. ${ }^{25,26}$ Adult Leydig cells were also completely absent in Pdgfra-deficient mice, ${ }^{26}$ and thus, this growth factor may be essential for the proper development of adult Leydig cells. Cyclin D3, which is a known mediator of cell proliferation, regulates the checkpoint in DNA synthesis and transition of the phase from G1 into $S$ in the cell cycle. ${ }^{27}$ Plateletderived growth factor has been shown to regulate cell cycle progress by inducing Ccnd 3 expression. ${ }^{28,29}$ Thus, the observed low expression of Pdgfra after NAL treatment is consistent with the observed low expression of Ccnd3.

MENT treatment increased the mRNA levels of Pdgfra, Igf1, Bcl2, Ccnd 3 and Pcna (Figure 5). IGF-I is required for progenitor Leydig cell proliferation and it has been reported to stimulate DNA synthesis in progenitor Leydig cells in vitro. ${ }^{5}$ The IGF-I knockout mouse testis has only one-sixth the number of Leydig cells present in age-matched wild-type testis, ${ }^{30}$ most likely as the result of a reduced proliferation of progenitor Leydig cells. ${ }^{31}$ Leukemia inhibitory factor receptor ( $L i f r$ ) is present in the Leydig cell lineage, including mesenchymal cells. ${ }^{25,32}$ Leukemia inhibitory factor can maintain stem cell self-renewal in many types of stem cells, ${ }^{33}$ including mesenchymal cells. ${ }^{25}$

Proliferating cell nuclear antigen, a cell-cycle marker protein, is an essential component for eukaryotic chromosomal DNA replication and repair. ${ }^{34}$ Our results showed that decreased Ccnd3 and Pcna mRNA levels coincided with the decreased proliferative capacity of progenitor Leydig cells, as assessed by the reduction in thymidine incorporation into the cell (Figure 3), and the decreased number of progenitor Leydig cells (Figure 4) after NAL treatment. Bcl2 is a negative regulator of cell survival and apoptosis ${ }^{35}$ and is present in Leydig cell precursor cells but not in terminally differentiated adult Leydig cells. ${ }^{36}$ Our observation that $B c l 2$ expression was maintained by androgen in NAL-treated animals (Figure 5) suggests that androgen is required for the suppression of apoptosis in progenitor Leydig cells. BCL2 and BAK protein, a pro-apoptotic member of the Bcl-2 gene family, are involved in initiating apoptosis.

In addition, we examined the mRNA levels of steroidogenic factor 1 (Nr5a1) and 3ßSHD1 (Hsd3b1). Steroidogenic factor 1 was identified as a tissue-specific transcriptional regulator of cytochrome P450 steroid hydroxylases in Leydig cells ${ }^{37}$ and $3 \beta$ HSD1 is known as a Leydig cell-specific mRNA transcript. These transcript levels were decreased by NAL treatment. Furthermore, LH, but not MENT treatment, resulted in higher levels of Nr5a1 and Hsd3b1 mRNA compared to the untreated groups. It is important to identify distinct functions of $\mathrm{LH}$ and androgen, and it is likely that $\mathrm{LH}$ administration induced androgen production in NAL-treated rats. However, androgen secreted from 14-day-old rat testis was mainly a weak androgen androsterone, ${ }^{10}$ which had nearly no androgen activity. We observed that LH selectively induced $N r 5 a 1$ and $H s d 3 b 1$ mRNAs, while androgen selectively induced $I g f 1$ and $B c l 2$ mRNAs, suggesting that these two hormones act on distinct signaling pathways.

In conclusion, the present study showed that suppression of endogenous LH and androgen resulted in a reduced proliferation of progenitor Leydig cells and a reduced expression of several genes. Our results support the conclusion that androgen contributes to signaling pathways mediated by several growth factors and suppresses apoptosis and that LH induces progenitor Leydig cell differentiation.

\section{AUTHOR CONTRIBUTIONS}

YX, RG were responsible for the concept and framework of the paper. JG, XM, CW, YG, QL, and YZ participated in collecting and evaluating the data. JG, QL, DOH and RG wrote the paper. YX and RG were responsible for the drafting and final editing. All authors read and approved the final manuscript.

\section{COMPETING FINANCIAL INTERESTS}

All authors declare that there are no competing financial interests.

\section{ACKNOWLEDGMENTS}

We are grateful to Ms Chantal Sottas for technical assistance. This work was in part supported by the National Nature Science Foundation of China (nos. 30871434 and 31171425 to RS Ge, no. 30900846 to CQ Wang and no. 81200430 to YF Zhang).

1 Shan LX, Phillips DM, Bardin CW, Hardy MP. Differential regulation of steroidogenic enzymes during differentiation optimizes testosterone production by adult rat Leydig cells. Endocrinology 1993; 133: 2277-83.

2 Mendis-Handagama SM, Ariyaratne HB. Differentiation of the adult Leydig cell population in the postnatal testis. Biol Reprod 2001; 65: 660-71.

3 Hardy MP, Zirkin BR, Ewing LL. Kinetic studies on the development of the adult population of Leydig cells in testes of the pubertal rat. Endocrinology 1989; 124: 762-70. 
4 Ge RS, Hardy MP. Regulation of Leydig cells during pubertal development. In: Payne $\mathrm{AH}$, Hardy MP, editors. The Leydig Cell in Health and Disease. Totowa: Humana Press; 2007. pp55-70.

5 Ge RS, Hardy MP. Decreased cyclin A2 and increased cyclin $\mathrm{G}_{1}$ levels coincide with loss of proliferative capacity in rat Leydig cells during pubertal development. Endocrinology 1997; 138: 3719-26.

6 Shan LX, Hardy MP. Developmental changes in levels of luteinizing hormone receptor and androgen receptor in rat Leydig cells. Endocrinology 1992; 131: 1107-14.

7 Murphy L, Jeffcoate IA, O'Shaughnessy PJ. Abnormal Leydig cell development at puberty in the androgen-resistant Tfm mouse. Endocrinology 1994; 135: 1372-7.

8 O'Shaughnessy PJ, Murphy L. Cytochrome P-450 17 alpha-hydroxylase protein and mRNA in the testis of the testicular feminized (Tfm) mouse. J Mol Endocrinol 1993 11: 77-82.

9 Shan LX, Bardin CW, Hardy MP. Immunohistochemical analysis of androgen effects on androgen receptor expression in developing Leydig and Sertoli cells. Endocrinology 1997; 138: 1259-66.

10 Ge RS, Hardy MP. Variation in the end products of androgen biosynthesis and metabolism during postnatal differentiation of rat Leydig cells. Endocrinology 1998; 139: 3787-95.

11 Shan L, Hardy DO, Catterall JF, Hardy MP. Effects of luteinizing hormone (LH) and androgen on steady state levels of messenger ribonucleic acid for $\mathrm{LH}$ receptors androgen receptors, and steroidogenic enzymes in rat Leydig cell progenitors in vivo. Endocrinology 1995; 136: 1686-93.

12 Hardy MP, Kelce WR, Klinefelter GR, Ewing LL. Differentiation of Leydig cell precursors in vitro: a role for androgen. Endocrinology 1990; 127: 488-90.

13 Payne AH, Downing JR, Wong KL. Luteinizing hormone receptors and testosterone synthesis in two distinct populations of Leydig cells. Endocrinology 1980; 106: 1424-9.

14 Teerds KJ, de Rooij DG, Rommerts FF, van den Hurk R, Wensing CJ. Proliferation and differentiation of possible Leydig cell precursors after destruction of the existing Leydig cells with ethane dimethyl sulphonate: the role of $\mathrm{LH} /$ human chorionic gonadotrophin. J Endocrinol 1989; 122: 689-96.

15 Dombrowicz D, Sente B, Closset J, Hennen G. Dose-dependent effects of human prolactin on the immature hypophysectomized rat testis. Endocrinology 1992; 130: 695-700.

16 Tenover JS, DahI KD, Vale WW, Rivier JE, Bremner WJ. Hormonal responses to a potent gonadotropin hormone-releasing hormone antagonist in normal elderly men. J Clin Endocrinol Metab 1990; 71: 881-8.

17 Misro MM, Ganguly A, Das RP. GnRH antagonist treatment affects nuclear size and membrane associated indentations in rat Leydig cells. Arch Androl 1991; 27: 25-33.

18 Sharpe RM, Fraser HM. Leydig cell receptors for luteinizing hormone releasing hormone and its agonists and their modulation by administration or deprivation of the releasing hormone. Biochem Biophys Res Commun 1980; 95: 256-62.

19 Huhtaniemi IT, Nikula H, Detta A, Stewart JM, Clayton RN. Blockade of rat testicular gonadotropin releasing hormone ( $\mathrm{GnRH}$ ) receptors by infusion of a $\mathrm{GnRH}$ antagonist has no major effects of Leydig cell function in vivo. Mol Cell Endocrinol 1987; 49: 89-97.

20 Sharpe RM, Fraser HM. Inhibition of maturational changes in Leydig cell function by treatment of rats with an agonist of LH-RH. J Reprod Fertil 1980; 60: 359-68.
21 Xu Q, Lin HY, Yeh SD, Yu IC, Wang RS et al. Infertility with defective spermatogenesis and steroidogenesis in male mice lacking androgen receptor in Leydig cells. Endocrine 2007; 32: 96-106.

22 Zhu LJ, Hardy MP, Inigo IV, Huhtaniemi I, Bardin CW et al. Effects of androgen on androgen receptor expression in rat testicular and epididymal cells: a quantitative immunohistochemical study. Biol Reprod 2000; 63: 368-76.

23 de Gendt K, Atanassova N, Tan KA, de Franca LR, Parreira GG et al. Development and function of the adult generation of Leydig cells in mice with Sertoli cell-selective or total ablation of the androgen receptor. Endocrinology 2005; 146: 4117-26.

24 Welsh M, Saunders PT, Atanassova N, Sharpe RM, Smith LB. Androgen action via testicular peritubular myoid cells is essential for male fertility. FASEB J 2009; 23 : 4218-30.

25 Ge RS, Dong Q, Sottas CM, Papadopoulos V, Zirkin BR et al. In search of rat stem Leydig cells: identification, isolation, and lineage-specific development. Proc Natl Acad Sci USA 2006; 103: 2719-24.

26 Gnessi L, Basciani S, Mariani S, Arizzi M, Spera G et al. Leydig cell loss and spermatogenic arrest in platelet-derived growth factor (PDGF)-A-deficient mice. Cell Biol 2000; 149: 1019-26.

27 Norris AJ, Griffey SM, Lucroy MD, Madewell BR. Cyclin D3 expression in normal fetal normal adult and neoplastic feline tissue. J Comp Pathol 2005; 132: 329-39.

28 Simeone-Penney MC, Severgnini M, Rozo L, Takahashi S, Cochran BH et al. PDGFinduced human airway smooth muscle cell proliferation requires STAT3 and the smal GTPase Rac1. Am J Physiol Lung Cell Mol Physiol 2008; 294: L698-704.

29 Dong F, Agrawal D, Bagui T, Pledger WJ. Cyclin D3-associated kinase activity is regulated by p27kip1 in BALB/c 3T3 cells. Mol Biol Cell 1998; 9: 2081-92.

30 Baker J, Hardy MP, Zhou J, Bondy C, Lupu F et al. Effects of an Igf 1 gene null mutation on mouse reproduction. Mol Endocrinol 1996; 10: 903-18.

31 Hu GX, Lin H, Chen GR, Chen BB, Lian QQ et al. Deletion of the Igf1 gene: suppressive effects on adult Leydig cell development. J Androl 2010; 31: 379-87.

32 Ge R-S, Dong Q, Sottas CM, Chen H, Zirkin BR et al. Gene expression in rat Leydig cells during development from the progenitor to adult stage: a cluster analysis. Biol Reprod 2005; 72: 1405-15.

33 Cheng L, Gearing DP, White LS, Compton DL, Schooley K et al. Role of leukemia inhibitory factor and its receptor in mouse primordial germ cell growth. Development 1994; 120: 3145-53.

34 Naryzhny SN. Proliferating cell nuclear antigen: a proteomics view. Cell Mol Life Sci 2008; 65: 3789-808.

35 Tsujimoto Y, Finger LR, Yunis J, Nowell PC, Croce CM. Cloning of the chromosome breakpoint of neoplastic B cells with the $(14 ; 18)$ chromosome translocation. Science 1984; 226: 1097-9.

36 Fujisawa M, Kanzaki M, Tatsumi N, Okuda Y, Okada H et al. Inhibition of apoptosis in cultured immature rat Leydig cells by human chorionic gonadotropin associated with Bcl-2 mRNA expression. Endocr Res 2000; 26: 59-70.

37 Park SY, Tong M, Jameson JL. Distinct roles for steroidogenic factor 1 and desert hedgehog pathways in fetal and adult Leydig cell development. Endocrinology 2007; 148: 3704-10. 